\title{
Rapid homogeneous assay for detecting antibodies against SARS-CoV-2
}

Juuso Rusanen ${ }^{1, *}$, Lauri Kareinen ${ }^{1}$, Lev Levanov ${ }^{1}$, Sointu Mero ${ }^{2}$, Sari H. Pakkanen²,3, Anu Kantele ${ }^{2,3}$, Fatima Amanat ${ }^{4,5}$, Florian Krammer ${ }^{4}$, Klaus Hedman ${ }^{1,6}$, Olli

Vapalahti $^{1,6,7}$, Jussi Hepojoki ${ }^{1,8}$

${ }^{1}$ Department of Virology, Medicum, Faculty of Medicine, University of Helsinki, Helsinki, Finland

${ }^{2}$ Human Microbiome Research Program, Faculty of Medicine, University of Helsinki, Helsinki, Finland

${ }^{3}$ Meilahti Vaccination Reasearch Center, MeVac, Inflammation Centre, Helsinki University Hospital and University of Helsinki, Helsinki, Finland

${ }^{4}$ Department of Microbiology, Icahn School of Medicine at Mount Sinai, NY, USA

${ }^{5}$ Graduate School of Biomedical Sciences, Icahn School of Medicine at Mount Sinai, NY, USA

${ }^{6}$ HUS Diagnostic Center, HUSLAB, Helsinki University Hospital and University of Helsinki, Helsinki, Finland

${ }^{7}$ Department of Veterinary Biosciences, Faculty of Veterinary Medicine, University of Helsinki, Helsinki, Finland

${ }^{8}$ Institute of Veterinary Pathology, Vetsuisse Faculty, University of Zürich, Zürich, Switzerland

*Corresponding author

Email: juuso.rusanen@helsinki.fi

Author Contributions: Conceptualization: J.R., K.H., O.V., J.H. Data curation: J.R., S.M. Formal analysis: J.R., L.K. Funding acquisition: K.H., O.V., J.H. Investigation: J.R., L.K., L.L., S.M., S.P., J.H. Methodology: J.R., L.L., F.A., F.K., J.H. Project administration: A.K., K.H., O.V., J.H. Resources: S.P., A.K., F.A., F.K., K.H., O.V., J.H. Supervision: K.H., O.V., J.H. Visualization: J.R., L.K. Writing: original draft: J.R., L.K., L.L., J.H. Writing: review and editing: J.R., L.K., L.L., S.M., S.P., A.K., F.A., F.K., K.H., O.V., J.H.

Competing Interest Statement: K.H., J.H. and O.V are among inventors in a patent WO2015128548 describing the LFRET assay utilized in the manuscript. 


\section{Abstract}

34 Accurate and rapid diagnostic tools are needed for management of the ongoing coronavirus 35 disease 2019 (COVID-19) pandemic. Antibody tests enable detection of individuals past 36 the initial phase of infection and will help to examine possible vaccine responses. The 37 major targets of human antibody response in severe acute respiratory syndrome 38 coronavirus $2(\mathrm{SARS}-\mathrm{CoV}-2)$ are the spike glycoprotein $(\mathrm{S})$ and nucleocapsid protein $(\mathrm{N})$. 39 We have developed a rapid homogenous approach for antibody detection termed LFRET 40 (protein L-based time-resolved Förster resonance energy transfer immunoassay). In 41 LFRET, fluorophore-labeled protein L and antigen are brought to close proximity by 42 antigen-specific patient immunoglobulins of any isotype, resulting in TR-FRET signal 43 generation.

44 We set up LFRET assays for antibodies against $\mathrm{S}$ and $\mathrm{N}$ and evaluated their diagnostic 45 performance using a panel of 77 serum/plasma samples from 44 individuals with COVID$46 \quad 19$ and 52 negative controls. Moreover, using a previously described S construct and a 47 novel $\mathrm{N}$ construct, we set up enzyme linked immunosorbent assays (ELISAs) for antibodies 48 against SARS-CoV-2 S and N. We then compared the LFRET assays with these enzyme 49 immunoassays and with a SARS-CoV-2 microneutralization test (MNT).

50 We found the LFRET assays to parallel ELISAs in sensitivity (90-95\% vs. 90-100\%) and 51 specificity (100\% vs. 94-100\%). In identifying individuals with or without a detectable 52 neutralizing antibody response, LFRET outperformed ELISA in specificity (91-96\% vs. 53 82-87\%), while demonstrating an equal sensitivity (98\%).

54 In conclusion, this study demonstrates the applicability of LFRET, a 10-minute 'mix and 55 read' assay, to detection of SARS-CoV-2 antibodies. 


\section{Introduction}

57

In October 2020, the number of confirmed cases in the ongoing coronavirus disease 2019 (COVID-19) pandemic, caused by the severe acute respiratory syndrome coronavirus 2 (SARS-CoV-2), exceeded 40 million, with over a million deaths ${ }^{1}$. Reliable diagnostic assays are needed for specific management of COVID-19 patients as well as for epidemic surveillance and containment ("Test, trace and isolate"). Nucleic acid tests (NAT) or antigen tests serve to detect acute SARS-CoV-2 infection, whereas antibody testing tells the past-infection and/or immunity status, at both individual and population levels. Hence, antibody tests can be used for determining seroprevalences, examining vaccine responses in study settings, or determining whether an individual needs a booster as in the case of e.g. hepatitis B vaccine. With COVID-19, antibody testing may be the key in reaching the diagnosis for a patient presenting when the viral RNA has already waned, e.g. with late thromboembolic complications or prolonged symptoms ${ }^{2}$. The most widespread methods in antibody detection are enzyme immunoassays (EIAs) and lateral flow assays (LFAs); the former tend to be highly specific and sensitive yet require dedicated infrastructure and labor, and deliver the results at best within hours, whereas LFAs are simple and rapid but may be of substandard diagnostic performance.

We have previously set up rapid homogeneous (wash-free) immunoassays utilizing timeresolved Förster resonance energy transfer (TR-FRET) ${ }^{3-8}$. For FRET to occur, two fluorophores, donor and acceptor, are brought to close proximity, allowing excitation of the former to result in energy transfer to the latter, which then emits photons at a distinct wavelength. The efficiency of FRET is inversely dependent on the distance between the two fluorophores, with a $50 \%$ efficiency typically achieved at 15 to $60 \AA$ A. To reduce background from the notoriously autofluorescent biological samples, a chelated lanthanide donor exhibiting long-lived fluorescence is employed, allowing for time-resolved measurement (TR-FRET). We have developed a rapid homogeneous TR-FRET -based immunoassay concept termed LFRET (protein L-based time-resolved Förster resonance energy transfer immunoassay) and demonstrated its excellent diagnostic performance in detection of antibodies against Puumala orthohantavirus nucleocapsid protein, Zika virus NS1 and the autoantigen tissue transglutaminase (tTG $)^{5,7,8}$. LFRET relies on simultaneous 
87 binding to the antibody of interest of its donor-labeled antigen and of an acceptor-labeled

88 protein L. If the patient's serum contains antibodies against the antigen, they bring the two

89 fluorophores to close proximity, generating a TR-FRET signal that indicates the presence

90 of the specific antibodies. Interestingly, a recent report describes a TR-FRET based 1-hour

91 assay for separate detection of anti-SARS-CoV-2 antibodies of diffent immunoglobulin

92 isotypes $^{9}$.

93 SARS-CoV-2 is an enveloped (+)ssRNA virus with a non-segmented $30 \mathrm{~kb}$ genome and

94 four structural proteins: spike $(\mathrm{S})$, envelope $(\mathrm{E})$, membrane $(\mathrm{M})$, and nucleocapsid $(\mathrm{N})$.

95 Protruding from the viral surface are transmembrane homotrimers of S, essential for host

96 cell entry. The glycoprotein $\mathrm{S}$ is proteolytically cleaved into subunits $\mathrm{S} 1$ and $\mathrm{S} 2$, of which

97 S1 contains the host cell receptor-binding domain (RBD), while S2 mediates fusion with

98 the host cell membranes ${ }^{10}$. Like $\mathrm{S}$, the $\mathrm{E}$ and $\mathrm{M}$ proteins are located on the viral envelope,

99 whereas $\mathrm{N}$ protein binds the viral RNA to form a ribonucleoprotein complex that is

100 encapsulated within the viral membrane.

101

102

103

104

105

106

107

108

109

110

111

112

113

114

115

116

Antibody responses to SARS-CoV-2 predominantly target the $\mathrm{S}$ and $\mathrm{N}$ proteins. In hospitalized patients, the median time from onset of symptoms to $\operatorname{IgA}, \operatorname{IgM}$ and $\operatorname{IgG}$ seroconversion has been observed to be 11-14 days, with almost all individuals seroconverting by day $21^{11-13}$. The antibody levels correlate with the severity of disease, with few patients apparently not seroconverting ${ }^{12}$. Moreover, a fraction of the seroconverters do not seem to generate detectable neutralizing antibodies ${ }^{14}$. The neutralizing antibody (NAb) response correlates with the presence of anti-S antibodies ${ }^{15,16}$, with most but not all NAbs targeting the $\mathrm{RBD}^{17}$. IgG levels to other human betacoronaviruses have been observed to peak within months of infection and to wane within some years thereafter ${ }^{18,19}$. Moreover, reinfections with seasonal human coronaviruses have been observed as early as 12 months from the previous infection ${ }^{20}$. As for SARS-CoV-2, the persistence of antibodies and the extent to which these provide protective immunity remains as of yet uncertain.

In this study we introduce rapid wash-free LFRET assays for detection of antibodies against SARS-CoV-2 $\mathrm{N}$ and $\mathrm{S}$ antigens and compare them with ELISAs and microneutralization. 


\section{Results}

\section{LFRET incubation time, cutoff values and performance}

LFRET assays for SARS-CoV-2 $\mathrm{S}$ and $\mathrm{N}$ were set up using Eu-labeled in-house antigens and AF-labeled protein L. First, the assay conditions were optimized separately for $\mathrm{S}$ and $\mathrm{N}$ using three known anti-S/-N ELISA-positive and three known anti-S/-N ELISA-negative samples (included in the full 129-sample panel). Thereafter the remaining 123 samples were tested in the optimized conditions. For detection of both anti-S and anti-N antibodies measurement at 7 minutes was found optimal.

Cutoffs for both anti-S and anti-N LFRET were set by measuring LFRET signals relative to buffer in 48 samples tested negative by anti-S and anti-N ELISA. The average plus four standard deviations (SD) was set as cutoff: $228.37+4 \times 27.59=338.76$ counts for anti-S and $220.94+4 \times 27.73=331.86$ counts for anti-N LFRET.

Performances of the anti-S and anti-N LFRET assays were then determined with the 129 samples including 77 sera or heparin/EDTA plasmas from 44 individuals with a previous RT-PCR-confirmed SARS-CoV-2 infection, four samples from four individuals negative for SARS-CoV-2 by both RT-PCR and serology, and 48 samples from individuals with a comprehensively negative SARS-CoV-2 serology. The sensitivities and specificities of SARS-CoV-2 anti-S and anti-N LFRET in detection of PCR-positive individuals were 87\% and 100\% \& 78\% and 100\%, respectively. The combined anti-S/-N LFRET sensitivity and specificity were $90 \%$ and $100 \%$ : if either anti-S or -N LFRET was positive, the composite result was considered positive (Table 1). The development of LFRET signals over time among patients with follow-up samples available is shown in Figure S1.

\section{ELISAs and microneutralization}

In order to compare the performance of LFRET with classical serology, we tested the set of samples described above with SARS-CoV-2 anti-S and anti-N IgA, IgM and IgG ELISAs as well as SARS-CoV-2 microneutralization. The panel of seronegatives was excluded from anti-N IgA and IgM as well as anti-S IgM ELISAs. Altogether 107 samples 
medRxiv preprint doi: https://doi.org/10.1101/2020.11.01.20224113; this version posted November 4, 2020. The copyright holder for this preprint (which was not certified by peer review) is the author/funder, who has granted medRxiv a license to display the preprint in perpetuity.

All rights reserved. No reuse allowed without permission.

145

147

148

underwent microneutralization, including 64 samples from RT-PCR positive patients and 43 seronegative samples. Microneutralization titers of $\geq 20$ were considered positive.

The ELISA cutoffs were set at average plus four standard deviations of absorbances measured from 14 serum samples from SARS-CoV-2 seronegative Department staff members.

The sensitivities and specificities of ELISA for anti-S IgA, IgG and $\operatorname{IgM}$ in samples from SARS-CoV-2 RT-PCR-positive individuals were $91 \%$ and $98 \%, 90 \%$ and $100 \% \& 66 \%$ and $100 \%$, respectively. The corresponding sensitivities and specificities of anti-N ELISA were $75 \%$ and $100 \%(\operatorname{IgA}), 92 \%$ and $94 \%(\operatorname{IgG}) \& 16 \%$ and $100 \%(\operatorname{IgM})$, respectively (Figure S2). Pearson correlation between anti-S and anti-N IgG ELISAs was 0.90, 0.79 between IgM ELISAs and 0.31 between IgA ELISAs.

\section{Comparison of LFRET, ELISA and microneutralization}

Comparison between the LFRET signals and ELISA absorbances is presented in Figure 2. For anti-N antibodies, the correlation between LFRET and IgA or IgM ELISA results was low $(\mathrm{R}=0.25$ for $\operatorname{IgA}$ and $\mathrm{R}=0.13$ for $\operatorname{IgM})$. With $\operatorname{IgG}$ ELISA a stronger correlation of $\mathrm{R}=0.62$ was seen, apparently hampered by saturation of the ELISA signal. For anti-Santibodies, correlations between $\operatorname{IgA}$, IgG and $\operatorname{IgM}$ ELISAs were $\mathrm{R}=0.52, \mathrm{R}=0.62$ and $\mathrm{R}=0.56$, respectively. Higher LFRET signals were seen in samples from patients with severe disease, especially in anti-S LFRET and when samples taken less than two weeks from onset were excluded (Figure S3). The agreement between anti-N ELISA and LFRET was $88-89 \%$, and that between anti-S ELISA and LFRET 96-98\% (Table S1). The samples representing discordance between PCR, LFRET and/or ELISA are detailed in Table S2.

The LFRET and ELISA results are compared with microneutralization titers in Figure 3. Spearman's rank correlation coefficient (rho) between anti-S LFRET and MNT was 0.87, whereas for anti-S IgG, IgA and IgM ELISAs it was 0.68, 0.86 and 0.81, respectively. Likewise, between anti-N LFRET and MNT Spearman's rho was 0.83, while 0.81, 0.69 and 0.61 for anti-N $\operatorname{IgG}, \operatorname{IgA}$ and $\operatorname{IgM}$ ELISAs. Higher neutralization titers were observed in samples from hospitalized individuals. Sensitivities and specificities of LFRET and 
medRxiv preprint doi: https://doi.org/10.1101/2020.11.01.20224113; this version posted November 4, 2020. The copyright holder for this preprint

(which was not certified by peer review) is the author/funder, who has granted medRxiv a license to display the preprint in perpetuity.

All rights reserved. No reuse allowed without permission.

173 ELISA in correctly identifying microneutralization-positive and -negative samples are 174 shown in Table S3.

\section{Receiver operating characteristic analysis}

176 We also rated the performances of both LFRET assays using receiver operating

177 characteristic (ROC) curves (Figure S4). The curves were plotted in RStudio (version

178 1.3.1073) with the ROCR library (version 1.0-11). With the assumption that a positive

179 result in either IgM, IgG or IgA ELISA for a given sample signifies 'true' positivity, the

180 respective areas under the curve (AUCs) for both anti-N and anti-S LFRET assays were

181 very high, 0.94 and 0.97. 
182

\section{Discussion}

We set up rapid LFRET immunoassays for detection of anti-SARS-CoV-2 S and $\mathrm{N}$ antibodies for identification of individuals exhibiting an immune response against SARSCoV-2. Management of both COVID-19 patients and the ongoing pandemic at the population level calls for accurate diagnostic tools applicable in various settings, including resource poor areas without central laboratory facilities. Antibody assays allow detection of individuals past the initial infection phase as well as assessment of a possible vaccine response.

We have previously applied LFRET to diagnostics of viral and autoimmune diseases. Here, we further reduced the incubation time from the prior 20-30 to 7 minutes without compromising sensitivity or specificity. The simple, rapid 'mix and read' workflow of the assay could allow faster turnaround time from sample arrival to results as well as higher throughput compared to the currently popular EIAs. Moreover, the ease and speed of performing LFRET makes it more feasible for use in diverse enviroments, including pointof-care and limited-resource settings.

Combined anti-S/-N LFRET (i.e. if either assay is positive, the composite result is positive) was equal to anti-S IgG ELISA in terms of sensitivity (90\%) and specificity (100\%) in identification of RT-PCR -positive individuals (Table 1). Considering that the median time from symptom onset to seroconversion is $1-2$ weeks for SARS-CoV-2 $2^{11-13}$, we can better assess the sensitivities of these assays by excluding samples taken before two weeks from symptom onset. Excluding these samples, the sensitivities of anti-S, anti-N and anti-S/-N LFRET are 95\%, 80\% and 95\%, respectively. Simultaneously, the sensitivities of anti-S/$\mathrm{N}$ IgG ELISAs increase to $97 \%, 100 \%$ and $100 \%$. Combining sensitivity and specificity into a single value, the AUCs of anti-N and -S LFRET assays - 0.94 and 0.97 - reflect excellent performance (Figure S4).

Anti-SARS-CoV-2 antibody levels are higher in patients with severe clinical presentation $^{12,15}$. Also in our study the LFRET signals of hospitalized patients exceeded those of non-hospitalized yet PCR-positive individuals (Figures 2 and S3). In the hospitalized COVID-19 patients, the sensitivity of both anti-S and anti-N LFRET increased 
212 to $100 \%$ by two weeks from symptom onset (Table 1), importantly for clinical use. In

213 follow-up, the LFRET signals first showed a rapid rise within three weeks from onset and 214 thereafter plateaued or slowly declined (Figure S1).

215 The agreement between ELISA and LFRET was high: 90\% for anti-N -antibodies and $216>95 \%$ for anti-S -antibodies (Table S1). With the anti-N and anti-S LFRET vs. IgG ELISA 217 results combined, the overall agreement between the methods in the entire study material 218 was 94\% (124/129 samples). A closer look at the discordance (Table S2) shows three 219 samples $(65,72$ and 86) from PCR-positive individuals who remained seronegative in both 220 LFRET and ELISA, likely due to early sampling (Figure S1). Four samples (71, 70, 7 and 221 24) were negative in LFRET but positive in PCR and ELISA: The first two were early 222 infection specimens (taken 8 and 13 days post onset of symptoms) positive in anti-N $\operatorname{IgA}$ 223 ELISA, suggestive of early IgA seroconversion, a phenomenon observed previously ${ }^{21}$. The 224 other two were taken 4 and 9 weeks after onset from non-hospitalized patients positive in 225 anti-S and -N IgG and/or IgA ELISAs. These ELISA reactivities were weak (Figure 2e), 226 suggesting that the negativity in LFRET might reflect lower analytical sensitivity. Two 227 samples $(82,92)$ were negative in LFRET and RT-PCR but positive in anti-N IgG ELISA. 228 Additionally, two samples $(103,121)$ were negative in LFRET and MNT, but positive in 229 either anti-N IgG ELISA or anti-S IgA ELISA. No false positives were observed in 230 LFRET.

231 In microneutralization, all but one of the reactive samples were also positive in anti-S 232 LFRET, IgG and IgA ELISA and anti-N IgG ELISA (Figure 3), the exception being an 233 ICU patient sampled 13 days after onset with an MNT titer of 20 and a positive anti-N $\operatorname{IgA}$ 234 ELISA (Table S2, sample 70). Some of the studied individuals who seroconverted did not 235 exhibit a detectable neutralizing antibody response, as observed previously ${ }^{14}$. Interestingly, 236 the specificities of the LFRET assays in identification of the non-neutralizing individuals 237 as negatives (91\% for $\mathrm{S}$ and $96 \%$ for $\mathrm{N}$ ) were higher than those of IgG ELISAs (87\% for $238 \mathrm{~S}$ and $82 \%$ for $\mathrm{N}$ ) (Table S3). This may be due to lower analytical sensitivity of LFRET, 239 as the undetectable neutralization could result from lower overall levels of anti-SARS240 CoV-2 antibodies in the LFRET-negative but ELISA-positive samples. Nevertheless, 241 among the assays evaluated, anti-S LFRET demonstrated the best overall performance in 
medRxiv preprint doi: https://doi.org/10.1101/2020.11.01.20224113; this version posted November 4, 2020. The copyright holder for this preprint (which was not certified by peer review) is the author/funder, who has granted medRxiv a license to display the preprint in perpetuity.

All rights reserved. No reuse allowed without permission.

242 identification of samples containing neutralizing antibodies, with a sensitivity of $98 \%$ and

243 a specificity of $91 \%$.

244 Our study has some limitations. First, our SARS-CoV-2 -positive samples originated from

245 symptomatic patients. Individuals with asymptomatic infection may mount a significantly

246 lower antibody response ${ }^{22}$, whereby the sensitivity of LFRET in such individuals might be

247 lower. A second limitation is that antibodies against other coronaviruses, especially the

248 widely circulating OC43, HKU1, NL63 and 229E, were not examined. Those antibodies

249 potentially cross-reacting in the SARS-CoV-2 assay could reduce its specificity. However,

250 the RT-PCR and neutralization results strongly indicate that the observed antibody

251 responses were SARS-CoV-2-specific.

252 In conclusion, this study demonstrates the applicability of the LFRET approach to

253 detection of SARS-CoV-2 antibodies. While in sensitivity and specificity the assay

254 appears to parallel ELISA, the new assay is as easy and rapid to perform as an LFA,

255 requiring only combination of the diluted sample with a reagent mix and reading the

256 result after 7 minutes. In prediction of neutralization capacity, the anti-S LFRET

257 outperformed ELISA in specificity, at equal sensitivity. 


\section{$258 \quad$ Materials and Methods}

259

260

\section{Samples}

This study included 77 serum/plasma samples from 40 individuals tested positive and four samples from four individuals tested negative for SARS-CoV-2 by RT-PCR from nasopharyngeal swab samples. The positive samples were taken at 8 to 81 days after onset of symptoms. Additionally, 48 serum samples from asymptomatic individuals with a comprehensively negative SARS-CoV-2 serology (Euroimmun IgG, IFA IgG virus, IFA IgG spike, microneutralization negative) were included in the study. The data and samples were collected under research permit HUS/211/2020 and ethics committee approval HUS/853/2020 (Helsinki University Hospital, Finland).

\section{Nucleic acid testing}

Nucleic acid testing for SARS-CoV-2 was done from nasopharyngeal swab samples with either the Cobas ${ }^{\circledR}$ SARS-CoV-2 test using the Cobas ${ }^{\circledR} 6800$ system (Roche Diagnostics, Basel, Switzerland), a protocol based on one previously described by Corman et al. ${ }^{23}$, or the Amplidiag® COVID-19 test (Mobidiag, Espoo, Finland).

\section{Molecular cloning}

For protein expression, we acquired the ZeoCassette Vector (pCMV/Zeo) from ThermoFisher Scientific, and excised the Zeocin resistance gene from the vector using FastDigest EcoRI and XhoI (ThermoFisher Scientific) according to manufacturer's protocol. The excised gene was agarose gel purified, blunted using T4 DNA polymerase (ThermoFisher Scientific), and purified using Ampure XP beads (Beckman Coulter) both following the manufacturer's protocol. The selection gene was inserted into pCAGGS/MCS and to the pCAGGS vector bearing SARS-CoV-2 S protein (described in 24,25 ) gene by treating the plasmids with FastDigest SapI/LguI (ThermoFisher Scientific) according to manufacturer's protocol, followed by blunting and purifications as above. The insert was ligated to the plasmids using T4 DNA ligase (ThermoFisher Scientific) according to manufacturer's protocol, the ligation products transformed into Escherichia coli (DH5a strain), followed by plating the bacteria onto LB plates with $100 \mu \mathrm{g} / \mathrm{ml}$ of 
ampicillin and $50 \mu \mathrm{g} / \mathrm{ml}$ Zeocin (ThermoFisher Scientific). After overnight incubation at $37^{\circ} \mathrm{C}$, single colonies were picked and grown in $5 \mathrm{ml}$ of $2 \mathrm{xYT}$ medium supplemented with $100 \mu \mathrm{g} / \mathrm{ml}$ of ampicillin and $50 \mu \mathrm{g} / \mathrm{ml}$ Zeocin overnight at $37{ }^{\circ} \mathrm{C}$. The plasmids were purified using GeneJET Plasmid Miniprep Kit (ThermoFisher Scientific), and plasmids bearing the insert identified by restriction digestion (FastDigest EcoRI, ThermoFisher

292 Scientific) and agarose gel electrophoresis. For both constructs, clones with the insert in 293 reverse and forward direction were selected for ZymoPURE II Plasmid Maxiprep Kit 294 (ZymoResearch) preparations done following manufacturer's guidelines. A synthetic 295 SARS-CoV-2 NP gene under Kozak sequence and a signal sequence MMRPIVLVLLFATSALA flanked by KpnI and SgsI restriction sites was obtained from

297 ThermoFisher Scientific. The SARS-CoV-2 NP cassette was subcloned into pCAGGS/MCS-Zeo-fwd vector and plasmid maxipreps prepared as described above.

Protein expression and purification

We initially attempted producing SARS-CoV-2 S protein in Expi293F cells utilizing the Expi293 Expression System (ThermoFisher Scientific). Briefly, the pCAGGS plasmid bearing codon-optimized SARS-CoV-2 $\mathrm{spike}^{24}$ was transiently transfected into Expi293F cells as advised ${ }^{24,25}$, except that we used spinner flasks (disposable $125 \mathrm{ml}$ spinner flask,

304 Corning) for the culture. Protein purification from supernatants collected at five days post transfection followed the protocol described ${ }^{25}$ and yielded $0.2-0.3 \mathrm{mg}$ per $100 \mathrm{ml}$ culture, in line with earlier reports ${ }^{24,25}$.

Next, we transfected adherent HEK293T cells with pCAGGS-SARS-CoV-S-Zeo plasmids using Fugene HD at 3.5:1 ratio, in suspension as described ${ }^{26}$. The transfected cells were plated onto six-well plates, and at $48 \mathrm{~h}$ post transfection subjected to Zeocin selection, 150 $\mu \mathrm{g} / \mathrm{ml}$ Zeocin in high glucose DMEM (Dulbecco's Modified Eagle's Medium, Sigma) supplemented with 5\% fetal bovine serum (Gibco) and $4 \mathrm{mM} \mathrm{L-glutamine.} \mathrm{Two} \mathrm{days} \mathrm{after}$ initiating the selection, the cells were trypsinized and transferred into fresh wells, with fresh media and antibiotics provided at 2 to 3 day intervals. Once confluent, the cells were trypsinized, counted (TC20 cell counter, Bio-Rad), diluted to $\sim 30$ cells $/ \mathrm{ml}$, and dispensed onto 96-well plates, $100 \mu 1$ per well. After confluency, we switched to serum-free FreeStyle 293 Expression Medium (ThermoFisher Scientific) with $100 \mu \mathrm{g} / \mathrm{ml}$ Zeocin, and incubated 
317 the cells at $37{ }^{\circ} \mathrm{C} 5 \% \mathrm{CO}_{2}$. At $48 \mathrm{~h}$, we analyzed the medium for the presence of SARS-

318 CoV-2 S protein by dot blotting, briefly $2.5 \mu \mathrm{l}$ of the supernatant was dried onto a 319 nitrocellulose membrane, the membrane blocked (3\% skim milk in Tris-buffered saline 320 with $0.05 \%$ Tween-20), washed, probed with rabbit anti-RBD (Sino Biological, 40592321 T62), washed, probed with anti-rabbit IRDye800 (LI-COR Biosciences), washed, and read using Odyssey Infrared Imaging System (LI-COR Biosciences). The clone with the highest amount of SARS-CoV-2 S protein in the cell culture supernatant, HEK293T-spike-D5, was then expanded in DMEM with 5\% FBS, $4 \mathrm{mM}$ L-glutamine and $100 \mu \mathrm{g} / \mathrm{ml}$ Zeocin, and ampouled for storage in liquid nitrogen. We adapted the HEK293T-spike-D5 cells for suspension culture by placing trypsinized cells into a spinner flask with Expi293 Expression Medium (ThermoFisher Scientific) with $100 \mu \mathrm{g} / \mathrm{ml}$ of Zeocin. We stored an aliquot of the adapted cells in liquid nitrogen and tested their ability to produce SARSCoV-2 S protein in both Expi293 and FreeStyle 293 Expression Medium (both ThermoFisher Scientific). Having been cultured in the spinner flask for 5 to 8 days, the cells reached a density of $>3 \times 10^{6}$ cells $/ \mathrm{ml}$. The protein from the supernatants was purified using the protocol described ${ }^{25}$, with yields of 0.8-1.2 $\mathrm{mg}$ per $100 \mathrm{ml}$ culture. SARS-CoV-2-NP-Zeo using Fugene HD, briefly, $100 \mu \mathrm{g}$ of the plasmid diluted into $10 \mathrm{ml}$ of OptiMEM (Sigma), $350 \mu \mathrm{l}$ of Fugene HD added followed by mixing and 15 min incubation at room temperature, after which the plasmid mix was added onto Expi293F cells in Expi293 Expression Medium at $2.5 \times 10^{6}$ cells $/ \mathrm{ml}$. The incubation of the transfected cells was continued for four days, after which the supernatant was collected, and the protein purified (yield approximately $1 \mathrm{mg}$ per $100 \mathrm{ml}$ culture) as described for $\mathrm{S}$ protein ${ }^{25}$. The remaining cells were treated with $0.25 \%$ Trypsin-EDTA (Sigma) to remove dead cells, and

341 after two washes were put back into the spinner flask with fresh Expi293 Expression 342 Medium supplemented with $100 \mu \mathrm{g} / \mathrm{ml}$ of Zeocin. Eventually a population of cells started 343 to proliferate (Expi-NP-zeo cells), and were aliquoted in liquid nitrogen. The protein 344 production and purification occurred as described above with yields of $\sim 1 \mathrm{mg}$ per $100 \mathrm{ml}$ 345 culture. 
We labeled the SARS-CoV-2 S and N proteins with the donor fluorophore europium (Eu) using QuickAllAssay Eu-chelated protein labeling kit (BN Products and Services Oy) according to the manufacturer's instructions to generate Eu-labeled $\mathrm{S}(\mathrm{Eu}-\mathrm{S})$ and $\mathrm{N}(\mathrm{Eu}-$ N). We also labeled recombinant protein L (Thermo Scientific) with the acceptor fluorophore Alexa Fluor 647 to generate AF647-labeled protein L (AF-L), as reported ${ }^{5}$. IgG-free bovine serum albumin (BSA) was from Jackson ImmunoResearch Inc.

\section{TR-FRET assays}

The LFRET assay was done as described ${ }^{5}$ and as briefly illustrated by the flowchart in Figure 1. For calculating the relative TR-FRET signal increase, we here replace the pool of negative sera with TBS-BSA (50mM Tris- $\mathrm{HCl}, 150 \mathrm{mM} \mathrm{NaCl}, \mathrm{pH} 7.4,0.2 \%$ BSA). To establish LFRET assays for $\mathrm{S}$ and $\mathrm{N}$, we optimized the component concentrations by crosstitration using three positive and three negative serum samples. For detection of anti-N antibodies, we found the optimal on-plate dilution for serum to be $1 / 25$, and the optimal on-plate concentrations for AF-L and Eu-N to be $500 \mathrm{nM}$ and $5 \mathrm{nM}$, respectively. For detection of anti-S antibodies, we found an on-plate dilution of 1/100 for serum, AF-L concentration of $250 \mathrm{nM}$ and Eu-S concentration of $5 \mathrm{nM}$ optimal. We measured TR-FRET at $0,7,15,22,30,45$ and 60 minutes after combining the reagents. TR-FRET counts were measured with Wallac Victor ${ }^{2}$ fluorometer (PerkinElmer) and normalized as described ${ }^{3}$.

\section{Enzyme linked immunosorbent assays (ELISAs)}

We set up the SARS-CoV-2 $\mathrm{S}$ protein ELISA as described ${ }^{25}$ with the following amendments. We coated the plates (ThermoScientific NUNC-immuno 446442 polysorp lockwell C8) with $50 \mathrm{ul} /$ well of antigens diluted $1 \mu \mathrm{g} / \mathrm{ml}$ into $50 \mathrm{mM}$ carbonate-bicarbonate buffer pH 9.6 (Medicago AB) and used 1-Step Ultra TMB-ELISA Substrate Solution (ThermoFisher Scientific). As secondary antibodies we made use of polyclonal rabbit antihuman IgA-horeseradish peroxidase (HRP), -IgM-HRP, and -IgG-HRP (all from Dako) at respective dilutions of $1: 5000,1: 1500$, and 1:6000. The colorimetric reaction was terminated by addition to $0.5 \mathrm{M}$ sulphuric acid (Fluka), and the absorbances recorded (HIDEX Sense) at $450 \mathrm{~nm}$. The N protein ELISA followed the same protocol.

\section{Microneutralization}


medRxiv preprint doi: https://doi.org/10.1101/2020.11.01.20224113; this version posted November 4, 2020. The copyright holder for this preprint

(which was not certified by peer review) is the author/funder, who has granted medRxiv a license to display the preprint in perpetuity.

All rights reserved. No reuse allowed without permission.

376 For the SARS-CoV-2 microneutralization assay we first cultured Vero E6 cells on 96-

377 well plates (Thermo Scientific) overnight at $+37^{\circ} \mathrm{C}$ in $2 \%$ MEM (Eagle Minimum

378 Essential Media [Sigma-Aldrich] supplemented with 2\% inactivated fetal bovine serum

379 [Thermo Scientific], $2 \mathrm{mM}$ L-glutamine [Thermo Scientific], 100 units penicillin, and

$380100 \mu \mathrm{g} / \mathrm{ml}$ streptomycin [Sigma-Aldrich]). The following day we made a two-fold

381 dilution series (1:20 to 1:1280) of the serum samples in 2\% MEM and combined $50 \mu 1$ of

382 each dilution with $50 \mu \mathrm{l}$ of virus (1000 plaque forming units (pfu)/ml in $2 \% \mathrm{MEM})$. The

383 serum-virus mixes were kept for $1 \mathrm{~h}$ at $+37^{\circ} \mathrm{C}$. The cells were inoculated with the serum-

384 virus mixes and grown in incubators at $+37^{\circ} \mathrm{C}$. After 4 days, the cultures were fixed with

385 formalin, stained with crystal violet and the neutralization titers recorded. 
medRxiv preprint doi: https://doi.org/10.1101/2020.11.01.20224113; this version posted November 4, 2020. The copyright holder for this preprint (which was not certified by peer review) is the author/funder, who has granted medRxiv a license to display the preprint in perpetuity.

All rights reserved. No reuse allowed without permission.

\section{Acknowledgments and funding information}

387

388 The authors wish to acknowledge Drs. Tomas Strandin and Eliisa Kekäläinen for helping

389 in sample collection. Reagent generation in the Krammer laboratory was supported by the

390 NIAID Centers of Excellence for Influenza Research and Surveillance (CEIRS) contract

391 HHSN272201400008C and the Collaborative Influenza Vaccine Innovation Centers

392 (CIVIC) contract 75N93019C00051.

393

394 The authors received funding for this work from the following sources: the Sigrid

395 Jusélius Foundation, the Magnus Ehrnrooth Foundation, Finnish Society of Sciences and

396 Letters, the Research Funds of University of Helsinki and Helsinki University Hospital

397 (TYH 2018322), Finska Läkaresällskapet, the Finnish Medical Foundation, Academy of

398 Finland (\#1308613, \#1336490, \#336439 and \#335527), Juho Vainio Foundation, Jane

399 and Aatos Erkko Foundation, the European Union Horizon 2020 programme VEO

400 (Versatile emerging infectious disease observatory, grant No. 874735) and from Private

401 donors through the University of Helsinki. 


\section{References}

1. WHO, Coronavirus disease (COVID-19) Weekly Epidemiological Update. https://www.who.int/publications/m/item/weekly-epidemiological-update---27october-2020 (27 October 2020).

2. J. Watson, A. Richter, J. Deeks. Testing for SARS-CoV-2 antibodies. BMJ. https://doi.org/10.1136/bmj.m3325 (8 September 2020).

3. S. Saraheimo et al., Time-resolved FRET -based approach for antibody detection a new serodiagnostic concept. PLoS One. 8, e62739 (2013).

4. S. Hepojoki et al., A protein L-based immunodiagnostic approach utilizing timeresolved Förster resonance energy transfer. PLoS One. 9, e106432 (2014).

5. S. Hepojoki, J. Hepojoki, K. Hedman, O. Vapalahti, A. Vaheri, Rapid homogeneous immunoassay based on time-resolved Förster resonance energy transfer for serodiagnosis of acute hantavirus infection. J Clin Microbiol. 53, 636640 (2015).

6. S. Hepojoki et al., Competitive Homogeneous Immunoassay for Rapid Serodiagnosis of Hantavirus Disease. J Clin Microbiol. 53, 2292-2297 (2015).

7. L. Kareinen et al., Immunoassay for serodiagnosis of Zika virus infection based on time-resolved Förster resonance energy transfer. PLoS One. 14, e0219474 (2019).

8. J. Rusanen et al., LFRET, a novel rapid assay for anti-tissue transglutaminase antibody detection. PLoS One. 14, e0225851 (2019).

9. Y. Hong et al., Rapid 'mix and read' assay for scalable detection of SARS-CoV-2 antibodies in patient plasma. medRxiv. https://doi.org/10.1101/2020.09.01.20184101 (3 September 2020).

10. A.C. Walls et al., Structure, Function, and Antigenicity of the SARS-CoV-2 Spike Glycoprotein. Cell. 181, 281-292.e6 (2020).

11. J. Zhao et al., Antibody responses to SARS-CoV-2 in patients of novel coronavirus disease 2019. Clin Infect Dis. https://doi.org/10.1093/cid/ciaa344 (28 May 2020).

12. Q.X. Long et al., Antibody responses to SARS-CoV-2 in patients with COVID-19. Nat Med. 26, 845-848 (2020).

13. P.H. Herroelen, G.A. Martens, D. De Smet, K. Swaerts, A.S. Decavele, Humoral Immune Response to SARS-CoV-2. Am J Clin Pathol. 154, 610-619 (2020).

14. F. Wu et al., Evaluating the Association of Clinical Characteristics With Neutralizing Antibody Levels in Patients Who Have Recovered From Mild COVID-19 in Shanghai, China. JAMA Intern Med. 180, 1356-1362 (2020).

15. N.M.A Okba et al., Severe Acute Respiratory Syndrome Coronavirus 2-Specific Antibody Responses in Coronavirus Disease Patients. Emerg Infect Dis. 26, 14781488 (2020).

16. P.M. Folegatti et al., Safety and immunogenicity of the ChAdOx1 nCoV-19 vaccine against SARS-CoV-2: a preliminary report of a phase $1 / 2$, single-blind, randomised controlled trial. Lancet. 396, 467-478 (2020).

17. P.J.M. Brouwer et al., Potent neutralizing antibodies from COVID-19 patients define multiple targets of vulnerability. Science. 369, 643-650 (2020).

18. H.M. Al-Abdely et al., Middle East Respiratory Syndrome Coronavirus Infection Dynamics and Antibody Responses among Clinically Diverse Patients, Saudi Arabia. Emerg Infect Dis. 25, 753-766 (2019). 
medRxiv preprint doi: https://doi.org/10.1101/2020.11.01.20224113; this version posted November 4, 2020. The copyright holder for this preprint (which was not certified by peer review) is the author/funder, who has granted medRxiv a license to display the preprint in perpetuity.

All rights reserved. No reuse allowed without permission.

19. W.C. Cao, W. Liu, P.H. Zhang, F. Zhang, J.H. Richardus, Disappearance of antibodies to SARS-associated coronavirus after recovery. $N$ Engl J Med. 357, 1162-1163 (2007).

20. A.W.D Edridge et al., Seasonal coronavirus protective immunity is short-lasting. Nat Med. https://doi.org/10.1038/s41591-020-1083-1 (14 September 2020).

21. A.J. Jääskeläinen et al., Evaluation of commercial and automated SARS-CoV-2 IgG and IgA ELISAs using coronavirus disease (COVID-19) patient samples. Euro Surveill. 25, 2000603 (2020).

22. Q.X. Long et al., Clinical and immunological assessment of asymptomatic SARSCoV-2 infections. Nat Med. 26, 1200-1204 (2020).

23. V.M. Corman et al., Detection of 2019 novel coronavirus (2019-nCoV) by realtime RT-PCR. Euro Surveill. 25, 2000045 (2020).

24. F. Amanat et al., A serological assay to detect SARS-CoV-2 seroconversion in humans. Nat Med. 26, 1033-1036 (2020).

25. D. Stadlbauer et al., SARS-CoV-2 Seroconversion in Humans: A Detailed Protocol for a Serological Assay, Antigen Production, and Test Setup. Curr Protoc Microbiol. 57, e100 (2020).

26. L Szirovicza et al., Snake Deltavirus Utilizes Envelope Proteins of Different Viruses To Generate Infectious Particles. mBio. 11, e03250-19 (2020). 


\section{SARS-CoV-2 N-/S-LFRET}

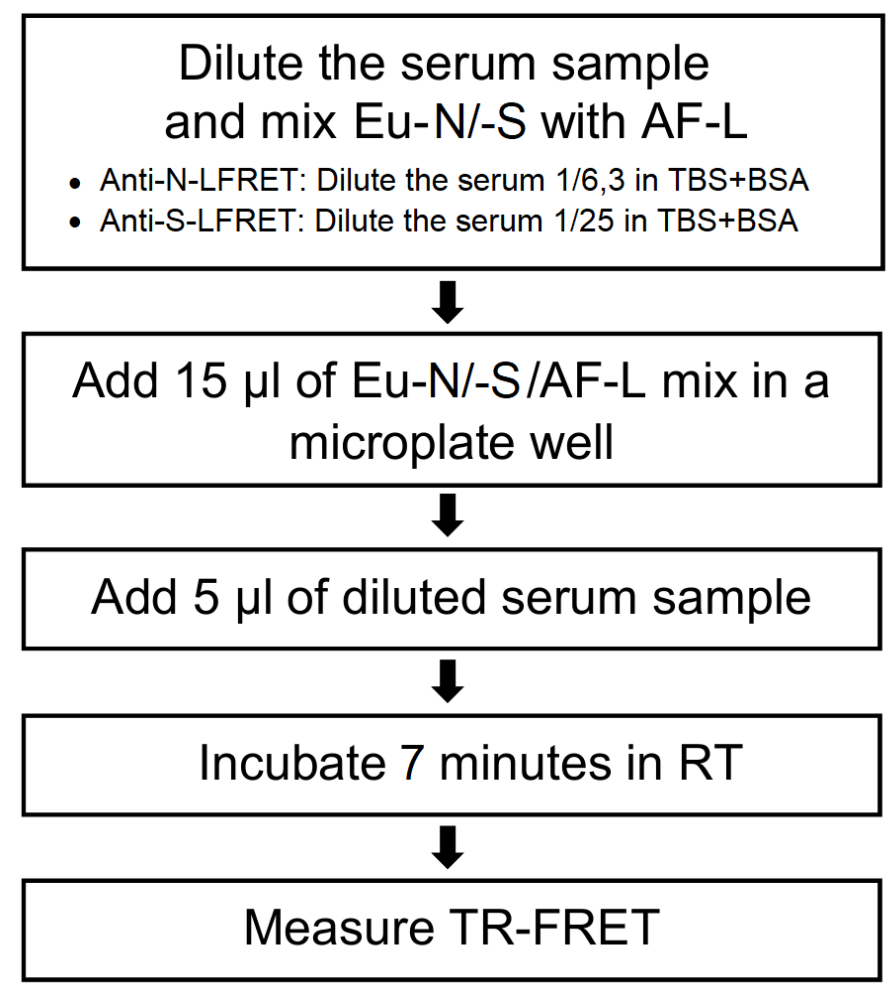

Figure 1. Simplified protocol for SARS-CoV-2 N and S LFRET assay. Eu-N/-S =

470 Europium-labeled nucleocapsid protein/spike glycoprotein. AF-L = Alexa Fluor ${ }^{\mathrm{TM}} 647$ -

471 labeled protein L. TR-FRET = time-resolved Förster resonance energy transfer. RT =

472 room temperature. TBS+BSA (50mM Tris- $\mathrm{HCl}, 150 \mathrm{mM} \mathrm{NaCl}, \mathrm{pH} \mathrm{7.4,0.2 \%} \mathrm{BSA})$ was

473 used for all dilutions. On-plate dilutions were $5 \mathrm{nM} \mathrm{Eu-N/500} \mathrm{nM} \mathrm{AF-L/serum} \mathrm{1/25} \mathrm{for}$

474 anti-N and $5 \mathrm{nM}$ Eu-S/250 nM AF-L/serum 1/100 for anti-S LFRET. For further details

475 see the prior publication ${ }^{5}$. 
a

Anti-N IgA ELISA vs. anti-N LFRET at 7 min

d

0.04

0.40
ELSA absorbance, $\log$ scale

Anti-S IgA ELISA vs. anti-S LFRET at 7 min

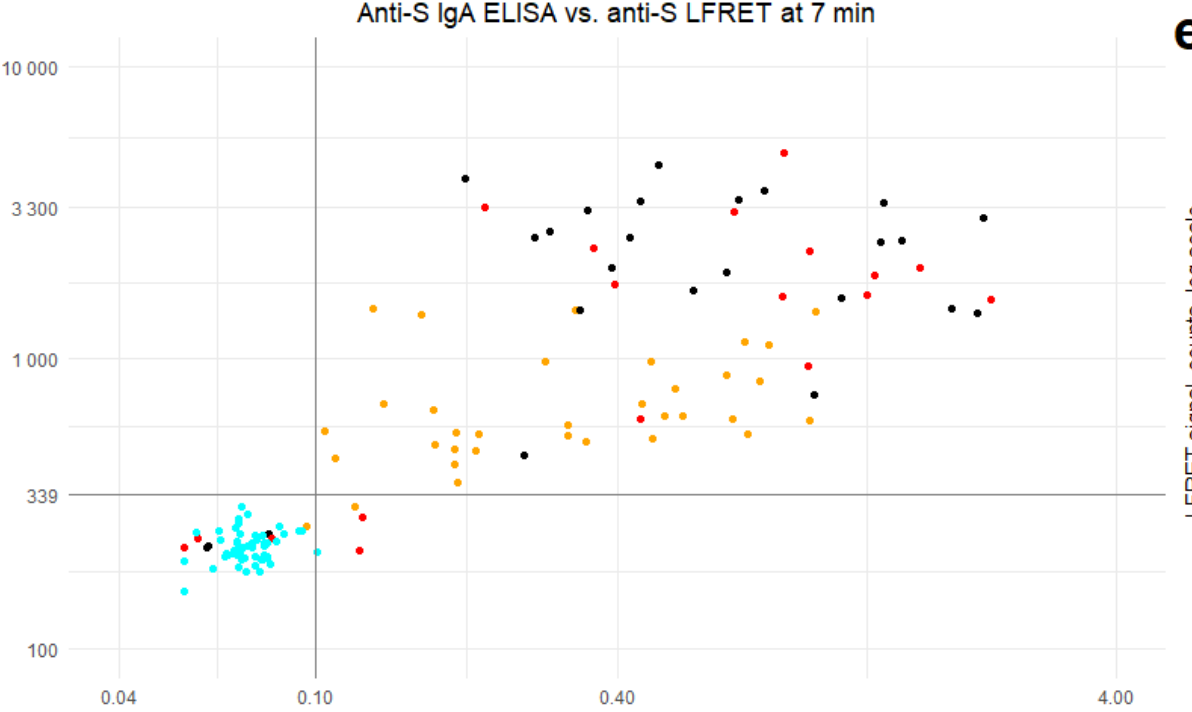

0.40
ELSA absorbance, log scale

b Anti-N IgG ELISA vs. anti-N LFRET at $7 \mathrm{~min}$
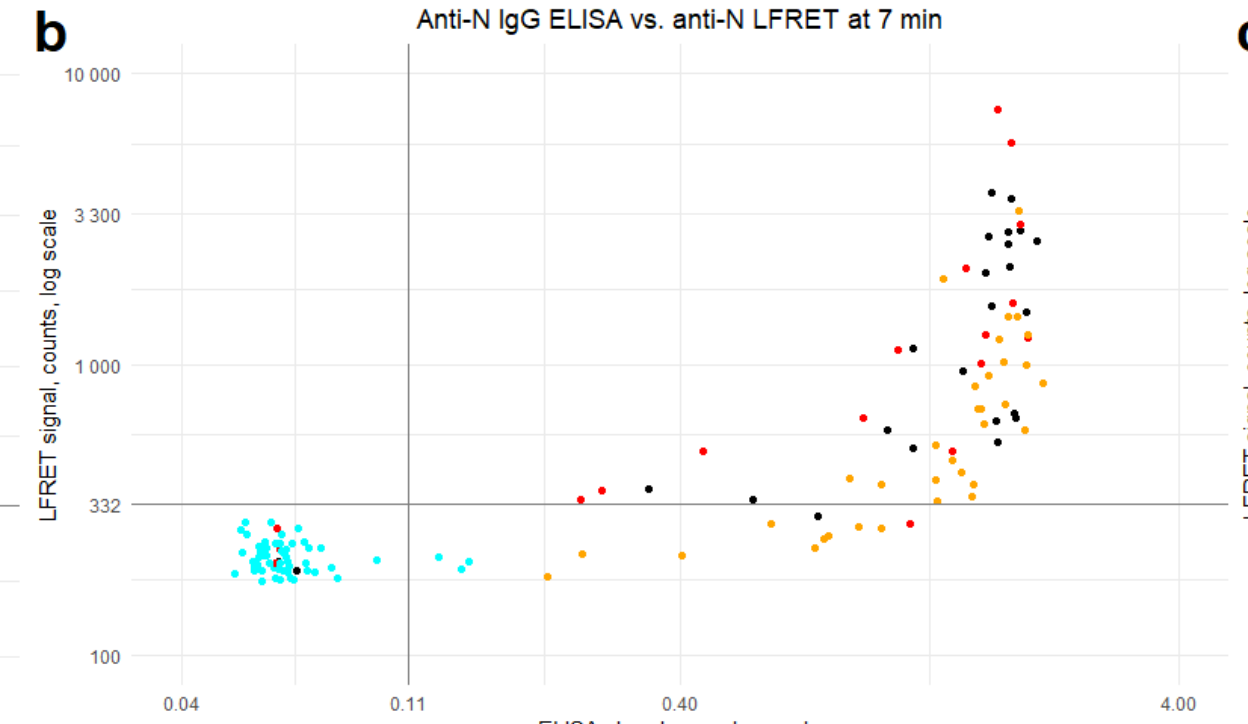

ELISA absorbance, log scale

Anti-S IgG ELISA vs. anti-S LFRET at $7 \mathrm{~min}$
C

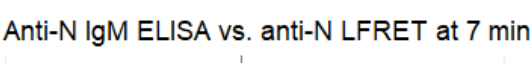

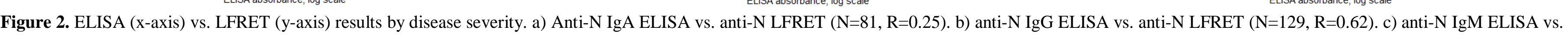

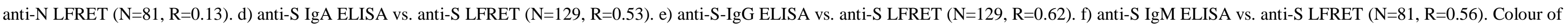

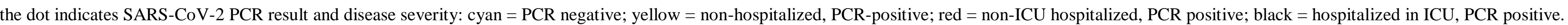

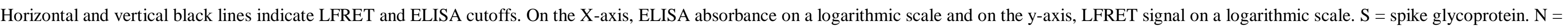
nucleocapsid protein. LFRET $=$ protein L-based time-resolved Förster resonance energy transfer immunoassay. ELISA = enzyme immunoassay. $\mathrm{R}=$ Pearson's correlation coefficient. 

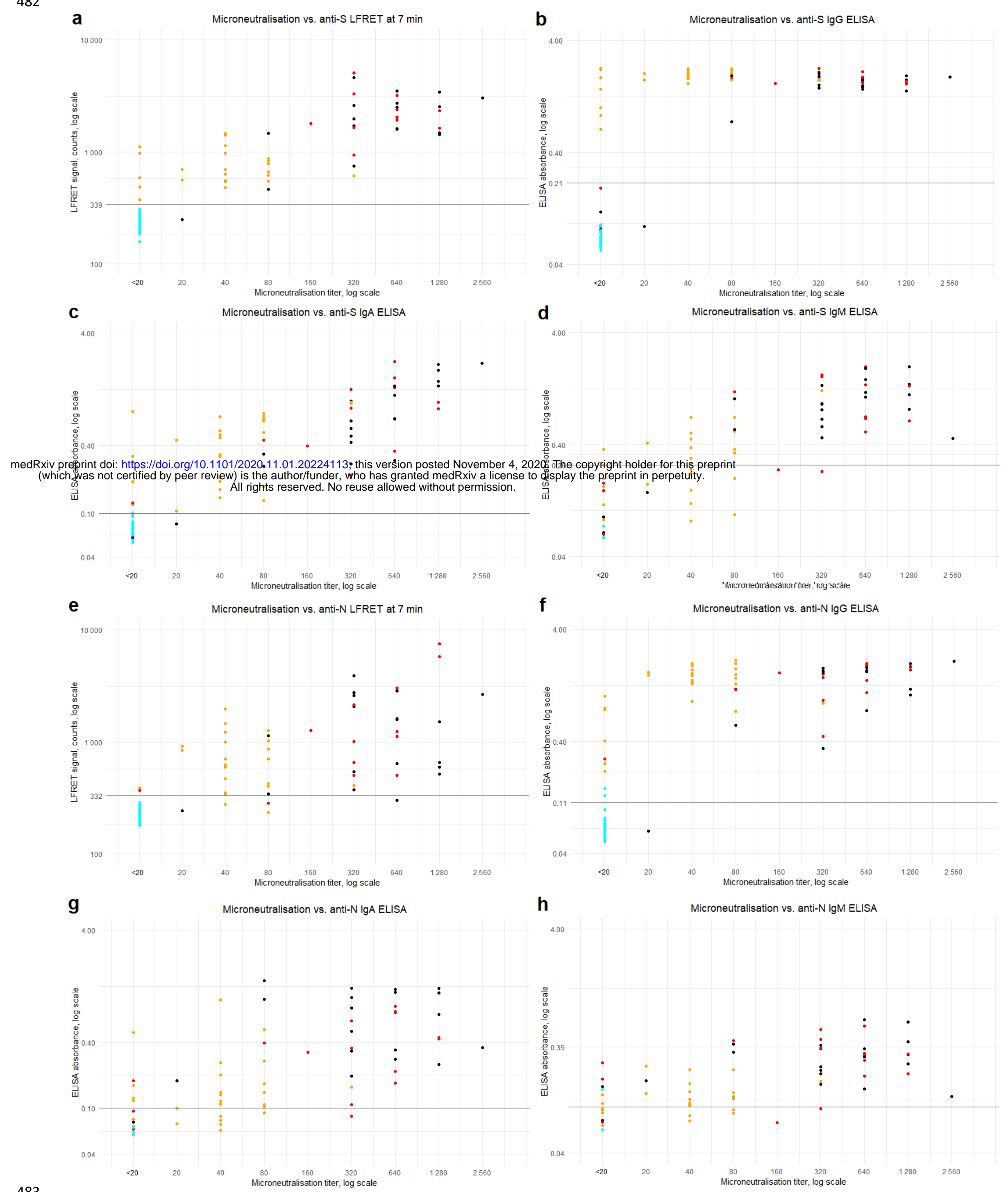

Figure 3. Microneutralization vs. LFRET and ELISA. Microneutralization titers are on the $\mathrm{x}$-axis and LFRET signal or ELISA absorbance on the $y$-axis. Logarithmic scale is used on both axes. a) Microneutralization titer vs. anti-S LFRET signal ( $N=107, \rho=0.87)$. b-d) Microneutralization titer vs. anti-S IgG, IgA and IgM ELISA ( $\mathrm{N}=107,107$ and 67, $\rho=0.68,0.86$ and 0.81). e) Microneutralization titer vs. anti-N LFRET signal ( $\mathrm{N}=107, \rho=0.83)$. f-h) Microneutralization titer vs. anti-N IgG, IgA and IgM ELISA (N=107, 67 and 67, $\rho=0.81,0.69$ and 0.61 ). Colour of the dots indicate SARS-CoV-2 PCR result and disease severity: cyan = PCR negative; yellow = nonhospitalized, PCR-positive; red = non-ICU hospitalized, PCR positive; black = hospitalized in ICU, PCR positive. Horizontal black lines indicate LFRET/ELISA cutoffs. $\mathrm{S}=$ spike glycoprotein. $\mathrm{N}=$ nucleocapsid protein. LFRET = protein L-based time-resolved Förster resonance energy transfer immunoassay. ELISA = enzyme immunoassay. $\rho=$ Spearman's rank correlation coefficient. 
medRxiv preprint doi: https://doi.org/10.1101/2020.11.01.20224113; this version posted November 4, 2020. The copyright holder for this preprint (which was not certified by peer review) is the author/funder, who has granted medRxiv a license to display the preprint in perpetuity.

492 Table 1. Sensitivity and specificity of ELISA and LFRE 1 in in detection of SARS-CoV-

4932 -PCR-positive individuals for all patients and hospitalized patients at different time

494 points from symptom onset. Altogether twenty samples from ten PCR-positive 495 individuals for whom the onset of symptoms is unknown are excluded. Specificity is 496 calculated from non-hospitalized asymptomatic individuals. $\mathrm{N}=$ nucleocapsid protein. $497 \mathrm{~S}=$ spike glycoprotein. LFRET $=$ protein $\mathrm{L}-$ based time-resolved Förster resonance energy transfer immunoassay. ELISA = enzyme-linked immunosorbent assay.

\begin{tabular}{|c|c|c|c|c|c|c|}
\hline \multirow[t]{2}{*}{$\begin{array}{l}\text { Patient } \\
\text { group }\end{array}$} & \multicolumn{3}{|c|}{ S LFRET sensitivity / specificity } & \multicolumn{3}{|c|}{$\begin{array}{l}\text { S IgG ELISA sensitivity / } \\
\text { specificity }\end{array}$} \\
\hline & $\begin{array}{l}\text { All } \\
\text { samples }\end{array}$ & $\begin{array}{l}>8 \text { days } \\
\text { after } \\
\text { onset }\end{array}$ & $\begin{array}{l}>13 \text { days } \\
\text { after onset }\end{array}$ & $\begin{array}{l}\text { All } \\
\text { samples }\end{array}$ & $\begin{array}{l}>8 \text { days } \\
\text { after onset }\end{array}$ & $\begin{array}{l}>13 \text { days } \\
\text { after } \\
\text { onset }\end{array}$ \\
\hline All patients & $\begin{array}{l}87 \% / \\
100 \%\end{array}$ & $\begin{array}{l}92 \% / \\
100 \%\end{array}$ & $\begin{array}{l}95 \% / \\
100 \%\end{array}$ & $\begin{array}{l}90 \% / \\
100 \%\end{array}$ & $\begin{array}{l}96 \% / \\
100 \%\end{array}$ & $\begin{array}{l}100 \% / \\
100 \%\end{array}$ \\
\hline \multirow[t]{2}{*}{ Hospitalized } & $\begin{array}{l}83 \% / \\
100 \%\end{array}$ & $\begin{array}{l}92 \% / \\
100 \%\end{array}$ & $\begin{array}{l}100 \% / \\
100 \%\end{array}$ & $\begin{array}{l}83 \% / \\
100 \%\end{array}$ & $\begin{array}{l}92 \% / \\
100 \%\end{array}$ & $\begin{array}{l}100 \% / \\
100 \%\end{array}$ \\
\hline & \multicolumn{3}{|c|}{ N LFRET sensitivity / specificity } & \multicolumn{3}{|c|}{$\begin{array}{l}\text { N IgG ELISA sensitivity / } \\
\text { specificity }\end{array}$} \\
\hline All patients & $\begin{array}{l}78 \% / \\
100 \%\end{array}$ & $\begin{array}{l}81 \% / \\
100 \%\end{array}$ & $\begin{array}{l}80 \% / \\
100 \%\end{array}$ & $\begin{array}{l}92 \% / \\
94 \%\end{array}$ & $\begin{array}{l}98 \% / \\
94 \%\end{array}$ & $\begin{array}{l}100 \% / \\
94 \%\end{array}$ \\
\hline \multirow[t]{2}{*}{ Hospitalized } & $\begin{array}{l}79 \% / \\
100 \%\end{array}$ & $\begin{array}{l}92 \% / \\
100 \%\end{array}$ & $\begin{array}{l}100 \% / \\
100 \%\end{array}$ & $\begin{array}{l}86 \% / \\
94 \%\end{array}$ & $\begin{array}{l}96 \% / \\
94 \%\end{array}$ & $\begin{array}{l}100 \% / \\
94 \%\end{array}$ \\
\hline & \multicolumn{3}{|c|}{$\begin{array}{l}\text { S/N LFRET sensitivity / } \\
\text { specificity }\end{array}$} & \multicolumn{3}{|c|}{$\begin{array}{l}\text { S/N IgG ELISA sensitivity / } \\
\text { specificity }\end{array}$} \\
\hline All patients & $\begin{array}{l}90 \% \\
/ 100 \%\end{array}$ & $\begin{array}{l}94 \% / \\
100 \%\end{array}$ & $\begin{array}{l}95 \% / \\
100 \%\end{array}$ & $\begin{array}{l}92 \% / \\
94 \%\end{array}$ & $\begin{array}{l}98 \% / \\
94 \%\end{array}$ & $\begin{array}{l}100 \% / \\
94 \%\end{array}$ \\
\hline Hospitalized & $\begin{array}{l}86 \% / \\
100 \%\end{array}$ & $\begin{array}{l}96 \% / \\
100 \%\end{array}$ & $\begin{array}{l}100 \% / \\
100 \%\end{array}$ & $\begin{array}{l}86 \% / \\
94 \%\end{array}$ & $\begin{array}{l}96 \% / \\
94 \%\end{array}$ & $\begin{array}{l}100 \% / \\
94 \%\end{array}$ \\
\hline
\end{tabular}

